\title{
The Economic, Social, and Environmental Impacts of Farmers Markets: Recent Evidence from the US
}

\author{
Phillip Warsaw ${ }^{1, *(\mathbb{D}}$, Steven Archambault ${ }^{2} \mathbb{D}$, Arden $\mathrm{He}^{3}$ and Stacy Miller ${ }^{4}$ \\ 1 Department of Community Sustainability, Michigan State University, East Lansing, MI 48824, USA \\ 2 Department of Agribusiness and Food Industry Management, Cal Poly Pomona University, \\ Pomona, CA 91768, USA; sarchambault@cpp.edu \\ 3 Department of Planning and Landscape Architecture, University of Wisconsin-Madison, \\ Madison, WI 53706, USA; jhe264@wisc.edu \\ 4 Good Phyte Foods, Charlottesville, VA 22902, USA; goodphytefoods@gmail.com \\ * Correspondence: warsawph@msu.edu
}

Citation: Warsaw, P.; Archambault, S.; He, A.; Miller, S. The Economic, Social, and Environmental Impacts of Farmers Markets: Recent Evidence from the US. Sustainability 2021, 13, 3423. https://doi.org/10.3390/ su13063423

Academic Editors: Alfonso Morales and Piotr Prus

Received: 12 February 2021

Accepted: 16 March 2021

Published: 19 March 2021

Publisher's Note: MDPI stays neutral with regard to jurisdictional claims in published maps and institutional affiliations.

Copyright: (c) 2021 by the authors. Licensee MDPI, Basel, Switzerland. This article is an open access article distributed under the terms and conditions of the Creative Commons Attribution (CC BY) license (https:/ / creativecommons.org/licenses/by/ $4.0 /)$.

\begin{abstract}
Farmers markets are regular, recurring gatherings at a common facility or area where farmers and ranchers directly sell a variety of fresh fruits, vegetables, and other locally grown farm products to consumers. Markets rebuild and maintain local and regional food systems, leading to an outsized impact on the food system relative to their share of produce sales. Previous research has demonstrated the multifaceted impacts that farmers markets have on the communities, particularly economically. Recent scholarship in the United States has expanded inquiry into social impacts that markets have on communities, including improving access to fresh food products and increasing awareness of the sustainable agricultural practices adopted by producers, as well developing tools for producers and market stakeholders to measure their impact on both producers and communities. This paper reviews the recent scholarship on farmers markets to identify recent trends and synthesizes the current evidence describing the ways in which farmers markets contribute to the wellbeing of their communities, as well as identifying areas for additional future research.
\end{abstract}

Keywords: local food systems; public space; social capital; food access; economic impact; social impact; agroecological practices

\section{Introduction}

Farmers markets are regular or seasonal community gatherings where local farmers, ranchers, fishers, harvesters, food vendors, and artisans can sell their local and sustainably products directly to community members [1-3]. Since the United States Department of Agriculture (USDA) began recording the number of farmers markets in 1994, the prevalence has increased from 1755 to 8761 in 2019 [4]. According to the 2015 Local Food Marketing Practices Survey, farmers market sales consisted of $23 \%$ of direct-to-consumer farm sales, totaling $\$ 711$ million in revenue (USDA 2015). This growth may be attributed to grassroots promotion of farmers markets at the local level converging with an increase in the number of small farms and consumer interest and demand for fresh, high quality local foods $[5,6]$. Customers are also drawn to farmers markets for access to healthy food, social appeal, convenience, and atmosphere [7-13]. Farmers markets can contribute benefits towards public health, economic well-being, social engagement, and ecological concerns $[14,15]$.

The current iteration of United States farmers markets developed in the 1970s and evolved as it built organizational and structural elements and created principles for successful markets $[1,16]$. In response to grassroots pressure, federal initiatives such as the Farmer-to-Consumer Direct Marketing Act of 1976 and the Farmers Market Promotion Program of the 2002 Farm Bill developed and played significant roles in fostering the growth and development of farmers markets $[17,18]$. At the state and local levels, municipalities, main street organizations, and nonprofits embrace markets as economic and 
equity development strategies [19]. Federal and nonprofit food assistance programs may use farmers markets to increase access to fresh produce for individuals in underserved neighborhoods [20].

Due to their direct connection to both producers and end-users of food products, farmers markets contain multiple leverage points to improve health and ecological outcomes of the food system [2]. In 2008, Brown and Miller summarized the documented impacts of farmers markets on their local communities, finding that farmers markets generate significant economic benefits for both local economies and farmers [2]. In the following decade, the number of farmers markets in the US has grown by an additional $86 \%$. The continued rapid growth of farmers markets has resulted in a significant expansion of the literature investigating the structure and impact of local markets throughout the supply chain, including lines of inquiry not explored in 2008. In particular, there has been increased attention to the role of farmers markets in contributing to a socially and ecologically sustainable food system, as well as the potential and limitations of utilizing farmers markets to contribute to food security and justice efforts across the US. In addition, partnerships between academia and organizations supporting farmers markets have stimulated the development of new tools to allow markets to engage in "citizen science" to track and communicate the impact of their markets on local communities. This paper synthesizes the social ecological benefits of farmers markets within the broader food system and their potential role in building healthy, sustainable communities, updating the previous work produced by Brown and Miller [2]. In addition, this review examines market-specific elements that maximize chances for success and sustainability, including how farmers markets are organized and managed by community members to benefit local agriculture, encourage entrepreneurship, and support individual, social, and economic aspects of public health.

\section{Organizational Structure of Farmers Markets}

A given market's structure is determined by both its social mission and its organizational characteristics, such as size, business model, governance capacity, and available resources [21,22]. Most farmers markets are managed by a paid or volunteer market manager who runs day-to-day operations, as well as a governing body, such as a board of directors, that develops a mission statement, business plan, and by-laws [21,23-25]. Market operators create the market layout, manage staffing needs, formulate and enforce market policies, and ensure adequate and representative governance [22,26]. Understanding, navigating, and communicating relevant federal, state, and local policies to producers are all de facto parts of most market managers' responsibilities. Governance also includes facilitating a board of directors or an advisory committee to ensure representation of all relevant stakeholder groups (such as farmers, shoppers, allied governmental and nongovernmental organizations) and development of appropriate market policies [26].

Federal, state, and local agencies regulate farmers market business activities, some of which address public health and safety. Federal agencies (e.g., USDA and the Food and Drug Administration) may assign some food safety requirements pertaining to the production, harvest, post-harvest handling, and marketing of foods, as well as tax and labor laws pertaining both to farm businesses and farmers market organizations. State and local regulations vary by community and address some or all of the following: licensing, permits, collection and reporting of sales tax, labeling laws, food handling and preparation, food microbiological and chemical safety, labor issues, and farming practices. Often local regulations supersede state and federal regulations and therefore need to be considered during the creation of local farmers market regulations to avoid confusion or potentially contradictory or miscommunicated expectations [27]. A growing number of states, however, are attempting to simplify and streamline the duplicative or contradictory processes by which farmers sell and offer samples of their products at markets [28]. As markets grow in number, size, and product diversity, they must learn to interact comfortably with the plethora of official imperatives, restrictions, and fees that connect them to social, political, and economic systems. 
Organizational structure, goals, zoning regulations, nearby land uses, proximity to other markets, and simple availability of space can influence where farmers markets are located as well as their dates of operation. Seasonal farmers markets often require minimal physical facilities. According to the 2019 Farmers Market Manager Survey (FMMS), 21\% of markets operated year-round, and 36\% utilized temporary facilities in their operations. Set up of temporary facilities is relatively quick, inexpensive, and flexible, relying mostly on energy and muscle as opposed to brick and mortar. This flexibility helps markets in both rural and urban areas to provide access to healthy and affordable foods close to the neighborhoods where customers live [29-31]. Markets are also flexible in their ability to open in different areas on different days; while the 2019 FMMS indicates that a majority of markets operate on Saturday, at least $10 \%$ of markets surveyed nationally operate on each day of the week with the exception of Monday. In areas with a high density of farmers markets, this provides households with multiple opportunities to buy local food products during a typical week.

Zoning ordinances can establish community areas for farmers markets, modify permit requirements, and protect existing markets from re-development. Well-conceived farmers market zoning ordinances aim to locate markets on properties that have stable tenure and are accessible to prospective patrons, while also fostering community development by expanding access to fresh produce or bringing foot traffic to a neglected commercial district. Such policies encourage partnerships between farmers markets and communities, schools, local commerce or business organizations, hospitals, universities, and faith-based organizations [32]. Sometimes zoning ordinances even require farmers markets to accept food assistance benefits. For example, San Francisco's city code was amended in 2009 to require farmers markets operating within the city to accept various forms of food assistance, including SNAP (Supplemental Nutrition Assistance Program) benefits via Electronic Benefit Transfer (EBT) [33].

Common business models include independent nonprofits, private for-profits, private social enterprises with unofficial agreements among producers, public services sponsored by city or county governments, and even programs under the umbrella of existing agencies or organizations [22,25]. Many farmers markets operate under the umbrella of another organization and therefore are not recognized by the Internal Revenue Service (IRS). Incorporation of markets as nonprofit organizations by registering them with a state government as opposed to applying for tax-exempt status with the IRS has become increasingly common due to the legal challenges involved in filing IRS 501(c)(3) documentation; as of 2019, over $65 \%$ of farmers markets were registered as a nonprofit (USDA 2019). Despite difficulties, obtaining 501(c)(3) status from the IRS may help communicate a market's commitment to a broad social agenda due to the high transparency required by the IRS for federally incorporated nonprofits [23]. Federally recognized tax-exempt status exempts a market from federal, state, and often local taxes, and the 501(c)(3) statute allows them to accept tax-deductible donations and become eligible for a wider variety of private and government grant programs. Nonprofit status can help farmers markets attract local private and public partners who can help pay for start-up costs with financial contributions or in-kind donations. Beyond funding, these partnerships also serve to embed markets within the social fabric of their communities, enabling the pursuit of various social and economic objectives [34]. Figure 1 illustrates the avenues of community impact frequently pursued by local markets and their synergies across actors.

To attain financial sustainability, farmers markets must avoid dependence on grant support and be able to pay operational costs solely out of income derived from vendor fees and other market income. However, other markets, especially those whose primary purpose is to serve low-income or rural communities, may require outside funding for ongoing management and community outreach $[35,36]$. Over the last two decades, funding opportunities have expanded both in the diversity of funders and the total dollars available for market support, including grassroots neighborhood support, marketing assistance from agricultural extension services, in-store and online promotion by neighboring businesses, 
and federal funding. One prominent example is the growth of the USDA Agricultural Marketing Service's Farmers Market Promotion Program (FMPP) [37]. The FMPP was originally created in 2006, and over the last decade has expanded the total funding made available from $\$ 1 \mathrm{M}$ in 2006 to $\$ 15 \mathrm{M}$ in 2016 [38]. FMPP funds can be used to support a wide swath of functions for farmers markets, including training, community outreach, marketing, and purchase and operations of Electronic Benefit Transfer (EBT) machines.

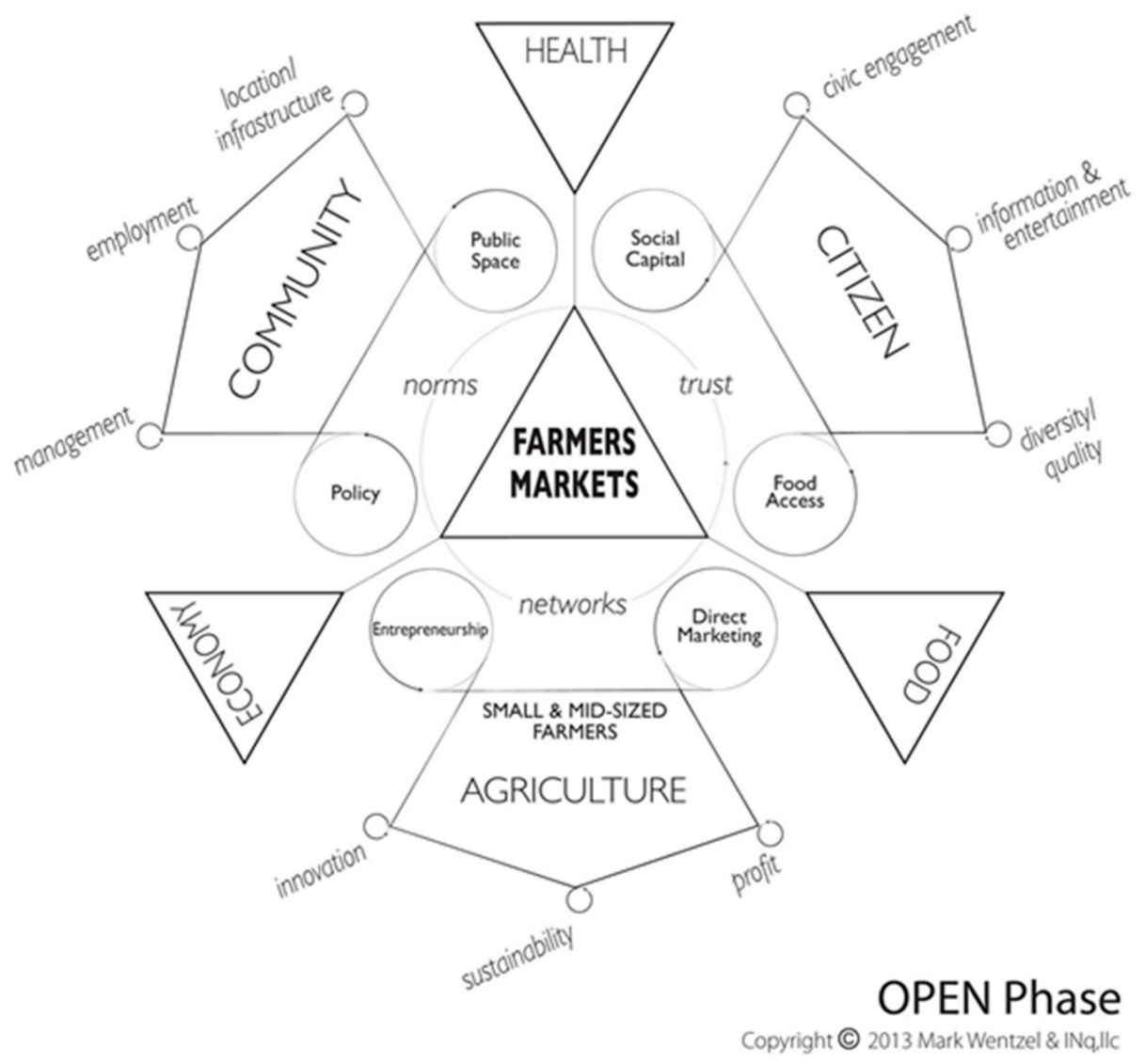

Figure 1. This framework illustrates the synergies created by farmers markets to benefit communities, individual citizens, and the farming community.

In addition to these forms of direct financial support, farmers markets are increasingly receiving indirect support from federal and state programs, such as the USDA Food and Nutrition Service's (FNS) Farmers Market Nutrition Program (FMNP) for participants in the Special Supplemental Nutrition Program for Women, Infants, and Children (WIC) and for low-income seniors (SFMNP). These programs bring business to markets by distributing vouchers to eligible low-income families and seniors that can only be redeemed at farmers markets. Other programs, such as Double Up Food Bucks and equivalent programs developed by non-profits such as the Wholesome Wave Foundation and the Fair Food Network work to increase the value of food assistance dollars by using matching funds from donors, programs inspired in part due to effort by the former First Lady Michelle Obama $[39,40]$.

\section{Community and Citizen Impacts of Farmers Markets}

Farmers markets are social events that build, support, and link urban and rural communities by fostering economic opportunities, creating public space, and vitalizing neighborhoods. More specifically, markets connect citizens as neighbors, consumers, producers, and community groups to the food system, providing opportunities for social interaction, commerce, entertainment, and information transfer [41]. Bringing people 
together at markets can directly benefit public health by providing a source of healthy foods as well as fostering a social atmosphere that promotes interaction, education, and potentially positive behavior change [42,43]. Farmers markets provide opportunities for people to learn about food, where it comes from, and how to prepare it. By providing a new approach to food and its role in our lives, farmers market patrons' shopping behavior at conventional grocery outlets may also change. Table 1 summarizes the benefits to communities identified by the research since the Brown and Miller review.

The search for authenticity and connection to food and agriculture has created a cultural momentum heightening the demand for quality local foods produced using environmentally and socially conscious methods $[9,11,44-49]$. This desire of consumers to know where their food comes from and how it was produced stems, in part, from corporate consolidation in the food system and the resulting, at least perceived, negative consequences for public health and farm viability [50-52].

Table 1. Summary of benefits to communities identified since Brown and Miller (2008).

\begin{tabular}{cccc}
\hline Community Impact & Synthesis of Findings since 2008 & Cited Studies \\
\hline Food Access & $\begin{array}{c}\text { Prices for fresh produce in markets are competitive with local retailers. } \\
\text { Expansion of food assistance increases consumption of fresh produce. }\end{array}$ & $\begin{array}{c}\text { Market shoppers report increased willingness to try new food products, } \\
\text { greater awareness of agroecological practices. }\end{array}$ \\
\hline Citizen Awareness & $\begin{array}{c}\text { Markets foster social interactions between diverse community } \\
\text { members, act as a multipurpose gathering space. }\end{array}$ & [77-80] \\
\hline Social Cohesion & $\begin{array}{c}\text { Markets generate additional business for local businesses, increase } \\
\text { local circulation of money, increase farm employment. }\end{array}$ & {$[42,81-86]$} \\
\hline Economic Development & $\begin{array}{c}\text { Markets generate social capital that facilitates pursuit of broader } \\
\text { community objectives such as public health. Lack of racial diversity } \\
\text { among markets may make markets a driver of gentrification. }\end{array}$ & {$[10,103-121]$} \\
\hline Contribution to Social Justice
\end{tabular}

The community relationships undergirding the formation and provision of local farmers markets create possibilities for innovation and efficiency while advancing social and ecologic ideals. These relationships can lead to new marketing opportunities and greater availability of affordable, healthful foods for citizens [29,31]. Markets are often a venue for civic engagement, where local champions-frequently volunteers-and nontraditional coalitions of public agencies and nonprofit organizations act to generate a range of impacts on their communities, whether it be fostering the development of vibrant public spaces, promoting healthy eating, or connecting food eaters with food producers [42].

\subsection{Improving Food Access and Affordability}

Offering a viable alternative to conventional food retailers such as supermarkets is an important aspect of successful markets. Previous research has indicated that consumer preferences for food are sensitive to cost and the proximity of a food retailer to where households live, particularly in areas that have limited food access [53]. As a result, concerns about inadequate local access to healthy food options remains pervasive across disciplines, given persistent gaps in physical and economic access to supermarkets and other food retailers, particularly in urban areas [54]. These dynamics have generated interest among scholars in the potential of farmers markets as a mechanism to improve the availability of fresh food products to underserved communities [55].

Recent scholarship has found consistent evidence that the presence of a farmers market increases local food access, specifically from an economic perspective. Fruits and vegetables at farmers markets can be equivalent to or lower in cost than produce at conventional retail outlets, especially during peak seasons [56-59], and may even affect the prices of produce in local retailers [60]. In addition, the fact that federal food assistance is increasingly redeemable at farmers markets further bolsters the affordability of their 
food products. As of 2019, more than 4000 farmers market retailers, approximately half the number of all markets listed in the USDA Farmers Market directory, accepted some form of federal food assistance. SNAP benefits are most commonly accepted, followed by WIC FMNP, and the Senior Farmers' Market Nutrition Program coupons are also accepted at most of these markets [61,62], all of which are accepted by a majority of markets that accept federal food assistance. Food assistance programs have produced measurable improvements in economic access to and increased consumption of fresh produce, in some cases having residual impacts on produce consumption after the programs expired [63-68]. These efforts have been boosted over the last decade by nutritional education programs supported by SNAP-Ed, which have consistently increased the usage of SNAP benefits at local markets [69,70], though barriers remain in making markets readily available to SNAP recipients [71].

Federal and state food assistance at farmers markets may be complemented with additional financial incentives, most of which are privately funded. These include matching incentives, such as Double Up Food Bucks, which match federal food assistance dollars spent at farmers markets. Studies evaluating these programs have found consistently positive impacts on the consumption of fruits and vegetables for participating consumers [68,72-74], though barriers to participating remain, particularly for households of color $[75,76]$.

\subsection{Supporting Sustainable Agriculture}

Related to the increased provision of fresh produce and other food products to local communities, farmers markets serve to meet a growing demand for locally grown food products produced using ecologically sensitive techniques. Dating back to the review written by Brown in 2002, scholars have consistently found that farmers market shoppers are not motivated solely (or even primarily) by the cost of food but rather by a broader set of characteristics including the growing practices used by the producer, the perceived quality of the products, and a desire to support local grower, findings further supported by research over the last decade [8,77].

There is a growing body of literature indicating that this demand is amplified by direct interactions with food producers. Farmers can act as food emissaries, introducing new foods or varieties through partnerships with chefs (e.g., hosting cooking demonstrations and tastings at farmers markets), restaurants, schools (e.g., supplying goods directly or making them available to be picked up at the market), and cooperative extension agents. The intimate relationship with consumers and unique characteristics [2] of individual markets based on geography or customer base encourages farmers to experiment with new crops and varieties, such as those with a particular ethnic appeal or targeted to consumers interested in trying new or exotic foods [2,78]. Many farmers selling at markets value the interaction with customers and, "after the drudgery of production, harvesting, and transporting, enjoy telling the story behind the food to customers" [78]. This storytelling is more than an attempt to sell a product, helping to valorize both the food and the process. Communicating the history, origin, growing conditions, preparation methods, and anecdotes behind the food builds an unintentional mythology that may later be repeated by a chef to a customer or by a parent to her family at the table [79]. These exchanges can elevate the social and cultural value of the farmers market and help raise the cultural status of fruits and vegetables, so they become a regular part of consumers' diets. This encourages consumers to choose from a selection of foods that changes seasonally, encouraging a positive feedback loop as consumers keep returning to see what is new and exciting at the market [80]. This newfound appreciation for food seasonality can spur eaters to adjust their cooking practices and diet by using foods that can be grown nearby, instead of using foods from the supermarket where seasonal changes are less evident because of global supply chains that span climatic zones and compress distance. 


\subsection{Community Revitalization and Economic Development}

As markets are increasingly recognized as community centerpieces, studies on farmers markets have documented the expanding multipurpose uses of these public spaces for nourishment, entertainment, education, and recreational activities. These include music, nutrition instruction, culinary demonstrations, seasonal produce tastings, and informational outreach by community groups $[42,81]$. As public spaces, markets can build community ties by facilitating social interactions and bridging economic, ethnic, and political divides $[43,82,83]$. Hosting multiple activities at farmers markets can expand the customer base by appealing to different needs, deepening the social and community cohesion fostered at markets, and making the markets themselves more sustainable [42].

As Brown and Miller note, farmers markets often serve as a catalyst for economic development and local business revitalization. Markets often generate increased foot traffic, which can spill over and benefit surrounding businesses. The market and its patrons create an active public space, which in turn attracts and encourages people to stay and participate in mercantile or social activities [84,85]. Depending on the locale and product mix, markets may attract tourists, further contributing to their economic impact. Farmers markets may also spur transactions with local businesses and local organizations via wholesale arrangements with restaurants or processors and donations to food pantries. Partnerships between agricultural producers and local businesses build trust, innovation, and connection between urban and rural communities [86].

Farmers markets produce economic impact through what is known as the multiplier effect, which is a general measure of the number of times money circulates at the local level and the resulting jobs created by these activities [43,87-93]. The direct purchases at farmers markets coupled with the indirect farmer expenditures on farm inputs, marketing supplies, and services contribute to the multiplier effect, along with subsequent induced effects from those suppliers and service providers spending money earned from farmers $[57,87,93,94]$. A higher multiplier effect indicates greater economic benefit to communities, stabilizing incomes, creating employment, and promoting investment growth and development of human capital. A study completed by Henneberry et al. of Oklahoma farmers markets had a collective multiplier of 1.78 , estimating that each dollar spent generated $\$ 1.78$ of total local economic activity. Given the $\$ 3.3$ million in total sales conducted at farmers markets that year, that resulted in a total economic impact of $\$ 5.90$ million [87].

However, the spending that occurs at farmers markets also tends to displace consumption at other food retailers, causing a slowdown in economic activity. These opportunity costs must be included in order to ensure an accurate estimate of the economic impact generated by farmers markets. For instance, in a study of a "locally grown" campaign targeting South Carolina farmers markets, Hughes and Isengildina-Massa found that while the program netted nearly $\$ 1$ million in increased output and income and netted 26.4 full-time equivalent jobs, the impact was much lower than the 10,000 jobs that had been reported by public outlets [92]. Due to these tradeoffs, local businesses selling similar products may perceive markets as competitors. While such concerns may have some merit, farmers markets generate local economic activity that tends to be greater than the activity lost through a decrease in spending at other retailers because farmers market sales recirculate more in the same locale, and farmers markets are more labor intensive than other food retailers [91]. In addition, the products available at markets are frequently unique in quality and variety, thus are unlikely to be found elsewhere. These characteristics fill a critical niche and reward farmers for crop diversity and innovation. However, some markets choose to limit or prohibit vending of prepared foods to maintain positive relations with neighboring food establishments [95-97].

While there is a growing interest on the part of farmers market managers and their stakeholders for measuring their economic impact, limited studies have been conducted attempting to measure this impact since the Brown and Miller review. This lack of research has been attributed to issues with data collection. Accurately measuring the economic impact of a farmers market relies on robust spending data by producers and consumers, 
which can be difficult to attain, particularly for markets with limited technical capacity and labor hours [98]. Recent scholarship has therefore focused both on improving data collection protocols and utilizing a diverse a holistic set of methodological approaches to capture economic impact, including the use of applied geography to illustrate the spatial reach of economic activity spurred by farmers markets [99,100].

These economic impacts are particularly relevant for low-income communities, where markets can be tools for neighborhood renewal and feed into comprehensive local economic development strategies [101]. Direct farm income stimulates employment opportunities and tax revenues in the surrounding urban and rural economies; it generates farm-level employment, purchases of agricultural inputs, and capital investment in land, materials, and machinery $[57,102]$. Markets may also decrease the economic costs of living in neighborhoods without supermarkets [60].

\subsection{Social Justice at Farmers Markets}

Given their ability to both provide economic revitalization and food access to local communities, a growing body of literature has employed social, environmental, and food justice frameworks when analyzing the impact of farmers markets on their local communities. Individual and social benefits radiate from enhanced access to healthy food in the socially positive community space generated by markets, wherein communities come together around food, health, jobs, economics, and the environment (Figure 1). Markets bring patrons into a defined physical area, which stimulates local business and generates community goodwill. Local artisans and crafts persons may also vend at markets and therefore increase the diversity and scale of foot traffic and strengthen cross-cultural ties to the community. In recent years, scholars have argued that highlighting the social, economic, and environmental relationships that govern agricultural production processes will generate consumer-led movements for building a sustainable and just food system [103].

The networks and the norms of reciprocity and trustworthiness created and strengthened by markets build social capital, which are the "institutions, relationships, and norms that shape the quality and quantity of a society's social interactions" [104,105]. Grassroots organizations build social capital by connecting community stakeholders, reinforcing trust, and engendering a feeling of ownership and civic responsibility [60,106-108]. Communities rich in social capital often have the resources that promote individual and public health goals, such as support, social trust, information, and membership $[60,109,110]$. Even controlling for socio-economic status, evidence suggests that stronger social capital at the household and community level increases household food security $[60,111]$. Social capital also is associated with decreased risk of hunger, meaning that farmers markets have potential to increase food security among vulnerable populations $[60,111]$.

However, this potential is often left unrealized due to the political and environmental values held by typical consumers and managers of local markets, who tend to be white, female, affluent, and well-educated, even in areas where white non-Hispanics are the minority $[10,103,112-119]$. These trends have been largely undisturbed by the expansion of federal food assistance at farmers markets; rather, shoppers on average are merely less affluent, but still overwhelmingly white, even among those using food assistance. In this case, the social capital generated by farmers markets acts as a draw to potential homeowners and renters looking to live in neighborhoods committed to sustainable values [120], increasing competition in local housing markets. As a result, there have been claims that farmers markets may unwittingly contribute to green gentrification and the displacement of low-income households of color in urban areas, despite nominal commitments to social justice and racial equity [121]. In response, there have been greater calls for stakeholders within farmers markets located in historically marginalized communities, particularly communities of color, to directly center the pursuit of social justice in their work for both consumers and producers, including broader socioeconomic representation among vendors and targeted outreach to communities underrepresented among farmers market shoppers [117]. 


\section{Farmers Market Impact on Producers}

\subsection{Economic Impact on Producers}

According to the USDA Economic Research Service, farmers received $22.8 \%$ of the retail value of food commodities sold for home consumption in 2013, below the average of $23.4 \%$ over the last 25 years and representing a multi-year decline in the share of food sales going to producers [122].

An alternative solution to declining farm share is reducing the number of intermediaries between farmers and consumers, as exemplified by the blossoming of directto-consumer marketing such as farmers markets. Shortening the supply chain usually provides farmers a higher share of the consumer dollar, allowing them to earn significantly higher revenue for a given crop compared to wholesaling [123]. The drawback of such channels is that they also demand more labor and materials for marketing and distribution than wholesale market channels [123], costs which farmers must control along with their production costs to be profitable [124]. Producers must therefore make tradeoffs between the lower volume and higher prices in direct-to-consumer sales, versus the higher volume and lower prices in wholesale markets [125].

These caveats aside, the low barriers to entry at farmers markets, resulting from the lack of minimum volume or standardization requirements, can spur formation of new farms or foster expansion and/or transformation of existing farms towards direct marketing and greater crop diversity $[126,127]$. Farmers markets facilitate enterprise development by giving direct and instant feedback to farmers on issues such as product quality, appearance, and taste, which assists producers' entry into market channels with higher barriers, such as Community Supported Agriculture (CSA) distribution, restaurants, institutional food service, and retail buyers [125,128-130]. This increased access to other marketing channels makes the indirect economic impact of farmers markets much greater than their direct impacts $[57,78,102]$.

Farmers markets encourage diversity in production methods and the crops grown. Directly connecting producers with consumers provides an avenue for direct economic feedback to producers on their growing practices, which in turn encourages the usage of organic or other ecologically sensitive techniques to remain competitive with other vendors at the market [128], ultimately giving consumers a measure of control in their local food system. This dynamic also encourages smaller farms to hedge risk by growing a diversity of crops possessing varying adaptability to environmental conditions. These crops are often delicate and highly perishable with specific growing windows, requiring a rapid harvest and marketing process. Local markets provide these farmers with the opportunity to experiment with market dynamics by introducing new or heritage varieties in small quantities [131], as well as the incentive to market the agroecological techniques used in their production to consumers. This product diversity serves as another selling point for customers, and markets that feature significant product diversity among its vendors are typically more financially successful [132], completing a virtuous circle of crop diversity.

Complementing the tendency to promote crop diversity, markets also tend to attract smaller farms as larger farms find it more difficult to adapt to the markets' demands [51]. Nationally, the number of farms within the US has continued to shrink, while average farm size continues to grow, indicating increasing levels of concentration in the agricultural sector. Bigger farms usually concentrate on a few crops and invest in highly mechanized approaches. Smaller farms, in turn, tend to use low-input agricultural methods or organic practices. When operating at a smaller scale, farmers can more intensively observe their land without relying on hired labor. This provides them with a better picture of how practices influence the farm's ecology and helps them find ways to improve production and manage pests without chemicals. Farmers market policies may or may not require vendors to be farmers, or that the food sold originates from farms within a specifically defined geographical radius [78]. The USDA Market Manager Survey found that $65 \%$ of markets require vendors to sell only the products they produce [133]. It can be difficult for 
small-scale local producers, strictly selling their own crops, to compete with vendors who sell foods purchased from wholesale venues or other farmers [41,78,133].

In their review, Brown and Miller discuss the research detailing the impact of farmers markets on producer incomes, noting that markets serve as a sole source of income for over 20\% of small producers, according to the 2006 Farmers Market Manager Survey [133]. Since then, there have been no similar studies characterizing more current trends in income generated by farmers markets. However, evaluation tools such as Farm2Facts and Farmers Market Metrics provide reporting tools for vendor income that may be applicable in future research (see Section 5). One relevant area on the frontier of research on farmer income is the potential over-saturation of markets. No academic research has been conducted on this topic to date, but journalistic reporting in the last two years has revealed a trend of smaller markets closing at increased rates in the last three years, with larger markets also seeing a decrease in revenue due to increased competition [134]. While the presence of multiple markets throughout a week may alleviate access concerns for consumers, traveling to multiple markets is costly for producers, while holding multiple markets on the same day risks dilution and divides the potential sales for vendors at each individual market. Theoretical and applied perspectives to model the relationship between market concentration and producer income would engage community organizations and stakeholders in decision making processes to determine the optimal number and locations of farmers markets. Table 2 summarizes the benefits to producers for participating in local markets since the Brown and Miller review.

Table 2. Summary of Farmers Market Impact on Producers.

\begin{tabular}{ccc}
\hline Producer Impact & Synthesis of Findings since 2008 & Cited Studies \\
\hline Small Farm Viability & $\begin{array}{c}\text { Smaller markets can be more competitive in markets than large } \\
\text { farms. Producer-only markets better protect small farmers. }\end{array}$ & {$[41,51,78,133]$} \\
\hline Diversification & $\begin{array}{c}\text { Consumer preferences and steady revenue encourage } \\
\text { production of multiple commodities. }\end{array}$ & {$[126-128,130,131]$} \\
Economic Benefits & $\begin{array}{c}\text { Markets offer higher margins on lower quantities sold } \\
\text { compared to wholesale market channels. Markets may also } \\
\text { serve as a conduit to other marketing channels. Oversaturation } \\
\text { may threaten market viability and farmer income. }\end{array}$ & {$[41,78,122-125,128-130,133,134]$,} \\
Ecological Practices & $\begin{array}{c}\text { Markets reduce food miles, but ecological impact of food } \\
\text { miles is unclear. Producers at markets engage in a wide } \\
\text { variety of ecologically responsible growing practices, } \\
\text { but impact of market participation on practices is unclear. }\end{array}$ & {$[48,123,135-143]$} \\
\hline
\end{tabular}

\subsection{Agroecological Impacts on Producers}

Brown and Miller's review called for new research analyzing the ecological impact of farmers markets. To date, limited research has been conducted on the direct impact of participating in markets on growing practices by vendors. A commonly cited benefit of farmers markets is the reduction in food miles that occurs when buying and selling from a farmers market. Many markets have strict limits on the distance food can travel to the market, and in general, food sold at a farmers market travels less than conventional food, which exceeds 1000 miles on average [135]. However, recent scholarship has called into question the value of food miles as a broad indicator of the climate impact of food choices [136-138], though the concept has value as an allegory representing the desire of consumers to reintegrate food production and consumption within local contexts [139]. A joint survey conducted by American Farmland Trust and Farmers Market Coalition found that $81 \%$ of producer respondents used one or more ecologically responsible practices, such as cover crops, reduced tilling, and other soil health practices on their farm [140]. In addition, Organic farmers engage in direct marketing more frequently than their conventional farmer peers $[48,123,141-143]$. However, despite a call from Brown and Miller in 
2008 for new scholarship quantifying the impact of markets on the adoption of ecologically sustainable practices by producers, we were unable to identify any articles that address this line of inquiry. However, given the existing literature suggesting that market shoppers have a preference for ecologically sustainable practices, as well as the economic incentives of individual producers to appeal to these preferences, this topic remains valuable for future research.

\section{Evaluating the Impact of Farmers Markets}

Another rapidly expanding segment of the literature on farmers markets explores the theoretical and methodological approaches to characterizing their impact on communities and farmers. As Brown and Miller note, this push towards evaluating the impact of farmers markets is attributed to the development of the rapid market assessment by Lev, Stephenson, and Brewer in 2007, with a primary focus at the time on assessing the economic impact generated by farmers markets. The 2006 Farmers Market Manager Survey did not feature a question measuring the adoption of assessment techniques by markets. In 2019, the Market Manager Survey included both questions, asking whether markets had conducted an assessment of their operations, as well as the type of assessment conducted. They found that $25.1 \%$ of survey markets had conducted an evaluation in the last year, encompassing a wide spectrum of objectives, including customer counts and product preferences, vendor needs, and sales information from producers [144], reflecting the growing diversity of methods and lines of inquiry among scholars. Given the multiple avenues by which markets can affect local food systems, there has been a growing recognition among researchers that maximizing their benefits requires a simultaneous effort to increase the frequency, location, and product diversity at markets, concurrent with an appropriate balance of patronage and supply. Focusing on single dimensions of market performance, such as the overall sales of the market, will not allow markets to realize their full potential to improve public health and community well-being at multiple scales and in multiple dimensions. Single focus or myopia can hinder the ability of markets to reach their full potential to positively impact community development and public health. For example, evaluating changes in fruit and vegetable access or intake as a result of targeted nutrition education interventions at markets is only one of many potential measures of the public health benefits [145], when market location and access to adequate transportation, among other factors, also influence the purchase of fresh produce at markets.

As a result, realizing the potential of farmers markets requires the use of transdisciplinary, trans-sector, and multilevel engagement of citizen, community, and agricultural stakeholders within the highly interconnected food, economic, and health systems (Figure 1) [146,147]. Assessing the impact of these interventions requires implementing a consistent data collection approach, which can be challenging for market managers, who are tasked with many different responsibilities, often with minimal budgets [148]. Several data collection tools have become available in the last decade to meet this need. For instance, Farm2Facts, a data collection tool developed and housed at the University of Wisconsin-Madison, is a citizen-science tool that enables individual markets to track and report their impact in the community through existing sources of potential secondary data such as vendor applications as well as simple primary data collection through customer and producer surveys [149-151]. This includes economic impact (e.g., the number of customers at the market and how much they spend at the market and at local businesses), social impact (e.g., food assistance spending, percentage of visitors who bike to the market), and is expanding its range of metrics to characterize ecological impact, though it currently tracks distance traveled by producers to the market. Another data collection tool to assist farmer market managers in tracking their impact is Farmers Market Metrics, developed by the Farmers Market Coalition, which offers a similar profile of metric collection and reporting. Placing farmers markets within the larger context of food, economic, and health systems can help planners, organizers, researchers, policy makers, and other farmers market stakeholders more effectively target potential points of intervention and anticipate the 
myriad consequences flowing from the complex social and cultural phenomenon that is the farmers market world [146,147].

\section{Conclusions}

Since the last review of farmers markets and their impact on local communities and producers by Brown and Miller, the scale and scope of these impacts have expanded significantly. Markets continue to function as an important economic engine, creating jobs by supporting small farm viability and acting as an incubator for broader business development, while also providing an attraction to increase commercial activity locally. However, recent scholarship has also illuminated the important role that farmers markets play in reducing food insecurity by granting communities access to fresh and affordable food products, particularly given the increase in federal, state, and private funds providing food assistance to food insecure households. In addition, markets have shown the potential to create a virtuous circle of sustainable agriculture practices by connecting producers directly with their customers, allowing producers to educate their patrons on the various agroecological techniques used in producing food, while simultaneously giving customers the ability to influence those practices through their purchasing behavior. The combined economic, social, and ecological impacts of farmers markets have also generated significant attention to the possibility of leveraging them to accomplish broader objectives related to social and environmental justice. To document these many impacts, new methodologies and tools have been developed to empower markets as citizen-scientists able to communicate the role of their market in their community and advocate for resources to further their social mission.

Despite the growing array of identified benefits provided by farmers markets, there are several avenues of research that remain open on the relationship between markets and communities. First, while there is some evidence of markets directly improving the sustainability of local food systems by creating more conscientious consumers and incentivizing producers to engage in agroecologically sustainable practices, there remains a dearth of literature explicitly connecting participation in a market to the adoption of farming practices that would otherwise not occur. In addition, while markets have documented the clear ability to increase local fresh produce consumption, these benefits are distributed unevenly, as structural and social barriers continue to prevent access to these spaces from reaching communities of color. Further, in some cases the presence of a market and the economic development it can bring has the secondary effect of displacing local households as housing costs rise. Thus, another area for additional research is identifying models and practices of socially just farmers markets that dimmish these barriers to access and ensure an equitable distribution of the benefits that markets provide to their local communities.

Author Contributions: Conceptualization, P.W. and S.M.; methodology, P.W.; formal analysis, P.W. and S.A.; writing — original draft preparation, P.W. and S.A.; writing —review and editing, P.W., S.A., and A.H. All authors have read and agreed to the published version of the manuscript.

Funding: This research received no external funding.

Institutional Review Board Statement: Not applicable.

Informed Consent Statement: Not Applicable.

Data Availability Statement: Not applicable.

Conflicts of Interest: The authors declare no conflict of interest.

\section{References}

1. Brown, A. Counting farmers markets. Geogr. Rev. 2001, 91, 655-674. [CrossRef]

2. Brown, C.; Miller, S. The Impacts of Local Markets: A Review of Research on Farmers Markets and Community Supported Agriculture (CSA). Am. J. Agric. Econ. 2008, 90, 1298-1302. [CrossRef]

3. Farmers Market Coalition. About Farmers Markets. Available online: https://farmersmarketcoalition.org/education/qanda/ (accessed on 1 March 2021). 
4. U.S. Department of Agriculture, Agricultural Marketing Service. Local Food Directories I Agricultural Marketing Service. Available online: https:/ / www.ams.usda.gov/local-food-directories/farmersmarkets (accessed on 3 December 2020).

5. Low, S.A.; Vogel, S. Direct and Intermediated Marketing of Local Foods in the United States. Econ. Res. Rep. USDA 2011, 128. [CrossRef]

6. Low, S.A.; Adalja, A.; Beaulieu, E.; Key, N.; Martinez, S.; Melton, A.; Perez, A.; Ralston, K.; Stewart, H.; Suttles, S.; et al. Trends in U.S. Local and Regional Food Systems: A Report to Congress; U.S. Department of Agriculture, Economic Research Service: Washington, DC, USA, 2015.

7. Garner, B.; Ayala, C. Regional tourism at the farmers' market: Consumers' preferences for local food products. Int. J. Cult. Tour. Hosp. Res. 2019, 13, 37-54. [CrossRef]

8. Giampietri, E.; Koemle, D.; Yu, X.; Finco, A. Consumers' sense of farmers' markets: Tasting sustainability or just purchasing food? Sustainability 2016, 8, 1157. [CrossRef]

9. Alonso, A.D.; O'Neill, M.A. A comparative study of farmers' markets visitors' needs and wants: The case of Alabama. Int. J. Consum. Stud. 2011, 35, 290-299. [CrossRef]

10. Byker, C.; Shanks, J.; Misyak, S.; Serrano, E. Characterizing Farmers' Market Shoppers: A Literature Review. J. Hunger Environ. Nutr. 2012, 12, 38-52.11. [CrossRef]

11. Conner, D.; Colasanti, K.; Ross, R.B.; Smalley, S.B. Locally Grown Foods and Farmers Markets: Consumer Attitudes and Behaviors. Sustainability 2010, 2, 742-756. [CrossRef]

12. Detre, J.; Mark, T.; Clark, B. Understanding Why College-Educated Millennials Shop at Farmers Markets: An Analysis of Students at Louisiana State University. J. Food Dist. Res. 2010, 41, 11.

13. Dodds, R.; Holmes, M.; Arunsopha, V.; Chin, N.; Le, T.; Maung, S.; Shum, M. Consumer Choice and Farmers' Markets. J. Agric. Enrion. Ethics 2014, 27, 397-416. [CrossRef]

14. Morales, A. Marketplaces: Prospects for Social, Economic, and Political Development. J. Plan. Lit. 2011, 26, 3-17. [CrossRef]

15. Schmit, T.; Jablonski, B.; Mansury, Y. Assessing the Economic Impacts of Local Food System Producers by Scale: A Case Study from New York. Econ. Dev. Q. 2016, 30, 316-328. [CrossRef]

16. Corum, V.; Rosenzweig, M.; Gibson, E. The New Farmers' Market: Farm Fresh Ideas for Producers, Managers, and Communities; New World Publishing: Auburn, CA, USA, 2001.

17. U.S. Department of Agriculture, Agricultural Marketing Service. Farmers Markets and Local Food Marketing: Farmers Market Promotion Program. Available online: https:/ /www.ams.usda.gov/services/grants/fmpp (accessed on 4 March 2021).

18. Becker, G.S. Farmers' Markets: The USDA Role; Congressional Research Service: Washington, DC, USA, 2006.

19. Deller, S.C.; Lamie, D.; Stickel, M. Local foods systems and community economic development. Community Dev. 2017, 48, 612-638. [CrossRef]

20. Freedman, D.A.; Flocke, S.; Shon, E.; Matlack, K.; Trapl, E.; Ohri-Vachaspati, P.; Osborne, A.; Borawski, E. Farmers' Market Use Patterns Among Supplemental Nutrition Assistance Program Recipients with High Access to Farmers Markets. J. Nutr. Ed. Behav. 2017, 49, 397-404. [CrossRef]

21. Lev, L.; Gwin, L. Filling in the Gaps: Eight Things to Recognize about Farm-Direct Marketing. Choices Mag. Food Farm Resour. Issues 2010, 25, 1-6.

22. Stephenson, G.; Lev, L. Farmers Market: Success, Failure, and Management Ecology; Cambria Press: Corvallis, OR, USA, 2008.

23. California Alliance of Farmers' Markets. Starting a Certified Farmers Market. Available online: https://farmersmarketalliance. org/resources / starting-a-certified-farmers-market/ (accessed on 1 March 2021).

24. Massachusetts Department of Agricultural Resources. How to Organize and Run a Successful Farmers' Market. Available online: https: / / www.mass.gov / guides/how-to-run-a-farmers-market (accessed on 4 March 2021).

25. Jolly, D. Farmers Market Management Skills. In Famers Market Management Series; University of California Small Farm Center: Davis, CA, USA, 2005.

26. Speier, J.A.; Krueger, J.E. Understanding Farmers' Market Rules. Available online: http://www.flaginc.org/wp-content/uploads/ 2013/03/FarmersMarket.pdf (accessed on 5 March 2021).

27. Miller, S.; Thompson, J.; Kalb, M. Healthy Foundations for Farmers Markets: Recommendations for Cities and Counties; Farmers Market Coalition: Albany, CA, USA, 2013.

28. Love, D. States Advocate for Legislation and Regulation to Support Home-Based Micro-Processing. Available online: http:/ / farmersmarketcoalition.org/states-advocate-for-legislation-and-regulation-to-support-home-based-micro-processing (accessed on 3 July 2012).

29. Pitts, S.B.J.; Gustafson, A.; Wu, Q.; Mayo, M.L.; Ward, R.K.; McGuirt, J.T.; Rafferty, A.P.; Lancaster, M.F.; Evenson, K.R.; Keyserling, T.C.; et al. Farmers' market use is associated with fruit and vegetable consumption in diverse southern rural communities. Nutr. J. 2014, 13, 1-11. [CrossRef]

30. Morales, A. Planning and the Self-Organization of Marketplaces. J. Plan. Ed. Res. 2010, 30, 182-197. [CrossRef]

31. Morales, A. Peddling policy: Street vending in historical and contemporary contest. Int. J. Soc. Social Policy 2000, 20, 76. [CrossRef]

32. Wooten, H.; Ackerman, A. From the Ground Up: Land Use Policies to Protect and Promote Farmers' Markets. Available online: https:/ / www.changelabsolutions.org/product/ground (accessed on 4 March 2021).

33. San Francisco, CA, US. Administrative Code §9A.15, 2009. Available online: http://sf-ca.elaws.us/code/adco_ch9a_sec9a.5 (accessed on 4 March 2021). 
34. Barroso-Méndez, M.J.; Galera-Casquet, C.; Valero-Amaro, V. The Importance of Relationship Learning in Private-Non-Profit Partnerships: Precursors and Outcomes. Int. J. Innov. Learn. 2016, 19, 169-187. [CrossRef]

35. Harris, D.; Lott, M.; Lakins, V.; Bowden, B.; Kimmons, J. Farm to Institution: Creating Access to Healthy Local and Regional Foods. Adv. Nutr. An Int. Rev. J. 2012, 3, 343-349. [CrossRef]

36. Markowitz, L. Expanding access and alternatives: Building farmers' markets in low-income communities. Food Foodways 2010, 18, 66-80. [CrossRef]

37. Curtin, A. Community-Funded Incentive Programs Galvanize Neighborhood Support for Food Equity in Portland; Farmers Market Coalition: Albany, CA, USA, 2011.

38. United States Department of Agriculture. 2016 Farmers Market Promotion Program Highlights. Available online: https: //www.ams.usda.gov/sites/default/files/media/FMPP2016Highlights.pdf (accessed on 1 March 2021).

39. Wholesome-Wave. Double Value Coupon Program: A 2011 Snapshot. Available online: http://www.calwic.org/storage/ documents / webinars / August_23-GusWICFarmersMarketWebinar.pdf (accessed on 2 March 2021).

40. Amaro, C.M.; Roberts, M.C. An evaluation of a dollar-for-dollar match program at farmers' markets for families using supplemental nutrition assistance program benefits. J. Child Fam. Stud. 2017, 26, 2790-2796. [CrossRef]

41. Kirwan, J. Alternative strategies in the UK agro-food system: Interrogating the alterity of farmers' markets. Soc. Rural. 2004, 44, 395-415. [CrossRef]

42. Project for Public Spaces. Public Markets as a Vehicle for Social Integration and Upward Mobility. Phase I Report: An Overview of Existing Programs and Assessment of Opportunities; Project for Public Spaces: New York, NY, USA, 2003.

43. McCarthy, R. Evaluating the Social, Financial and Human Capital Impacts of Farmers Markets; Market Umbrella: New Orleans, LA, USA, 2010.

44. Baker, D.; Hamshaw, K.; Kolodinsky, J. Who Shops at the Market? Using Consumer Surveys to Grow Farmers Markets: Findings from a Regional Market in Northwestern Vermont. J. Ext. 2009, 47, 1-9.

45. Hunt, A. Consumer interactions and influences on farmers' market income. Renew. Agric. Food Syst. 2007, 22, 54-66. [CrossRef]

46. Ilbery, B. Retailing local food in the Scottish-English borders: A supply chain perspective. Geoforum 2006, 37, 352-367. [CrossRef]

47. Govindasamy, R.; Italia, J.; Adelaja, A. Farmers' markets: Consumer trends, preferences, and characteristics. J. Ext. 2002, 40. [CrossRef]

48. La Trobe, H. Farmers' markets: Consuming local rural produce. Int. J. Consumer Stud. 2001, 25, 181-192. [CrossRef]

49. Hall, C.M.; Mitchell, R.; Scott, D.; Sharples, L. The authentic market experience of farmers' markets. In Food and Wine Festivals and Events around the World: Development, Management and Markets; Hall, C., Shaples, L., Eds.; Routledge: London, UK, 2008; pp. 197-231.

50. MacDonald, J.M.; Hoppe, R.A.; Newton, D. Three Decades of Consolidation in U.S. Agriculture; U.S. Department of Agriculture, Economic Research Service: Washington, DC, USA, 2018.

51. Feenstra, G.W.; Lewis, C.C.; Hinrichs, C.C.; Gillespie, G.W.; Hilchey, D. Entrepreneurial outcomes and enterprise size in US retail farmers' markets. Am. J. Altern. Agric. 2003, 18, 46-55. [CrossRef]

52. Hendrickson, M.K.; Heffernan, W.D. Opening Spaces through Relocalization: Locating Potential Resistance in the Weaknesses of the Global Food System. Soc. Rural. 2002, 42, 347-369. [CrossRef]

53. Brown, A. Farmers' market research 1940-2000: An inventory and Review. Am. J. Altern. Agric. 2002, 17, 167-176. [CrossRef]

54. Warsaw, P.; Phaneuf, D.J. The Implicit Price of Food Access in an Urban Area: Evidence from Milwaukee Property Markets. Land Econ. 2019, 95, 515-530. [CrossRef]

55. Schupp, J.L. Cultivating better food access? The role of farmers' markets in the US local food movement. Rural Sociol. 2017, 82, 318-348. [CrossRef]

56. Claro, J. Vermont Farmers' Markets and Grocery Stores: A Price Comparison; Northeast Organic Farming Association of Vermont: Richmond, VA, USA, 2011.

57. Otto, D.; Varner, T. Consumers, Vendors, and the Economic Importance of Iowa Farmers' Markets: An Economic Impact Survey Analysis; Leopold Center for Sustatainable Agriculture at Iowa State University: Ames, IA, USA, 2010.

58. Flaccavento, A. Is Local Food Affordable for Ordinary Folks? A Comparison of Farmers Markets and Supermarkets in Nineteen Communities in the Southeast; Rural SCALE, Inc.: Abingdon, VA, USA, 2011.

59. Harris, W. The Cost of Good Food. In Closer to Home: Healthier Food, Farms and Families in Oklahoma; McDermott, M., Ed.; Kerr Center for Sustainable Agriculture: Poteau, OK, USA, 2006; pp. 52-54, 162.

60. Larsen, K.; Gilliland, J. A farmers' market in a food desert: Evaluating impacts on the price and availability of healthy food. Health Place 2009, 15, 1158-1162. [CrossRef]

61. U.S. Department of Agriculture, Economic Research Services. Price Spreads from Farmer to Consumer. Available online: https:/ / www.ers.usda.gov/data-products/price-spreads-from-farm-to-consumer/ (accessed on 4 March 2021).

62. Farmers Market Coalition. SNAP Redemptions at Markets Continue to Increase, and New Federal Support is on the Way. 2014. Available online: https:/ / farmersmarketcoalition.org/2014-snap-update/ (accessed on 4 March 2021).

63. Anderson, J.V.; Bybee, D.I.; Brown, R.M.; McLean, D.F.; Garcia, E.M.; Breer, M.L.; Schillo, B.A. 5 a day fruit and vegetable intervention improves consumption in a low income population. J. Am. Diet Assoc. 2001, 101, 195-202. [CrossRef] 
64. Herman, D.R.; Harrison, G.G.; Afifi, A.A.; Jenks, E. Effect of a targeted subsidy on intake of fruits and vegetables among low-income women in the Special Supplemental Nutrition Program for Women, Infants, and Children. Am. J. Public Health 2008, 98, 98-105. [CrossRef]

65. Johnson, D.B.; Beaudoin, S.; Smith, L.T.; Beresford, S.A.; LoGerfo, J.P. Increasing fruit and vegetable intake in homebound elders: The Seattle Senior Farmers' Market Nutrition Pilot Program. Prev. Chronic Dis. 2004, 1, 1-9.

66. Kunkel, M.E.; Luccia, B.; Moore, A.C. Evaluation of the South Carolina seniors farmers' market nutrition education program. J. Am. Diet. Assoc. 2003, 103, 880-883. [CrossRef]

67. O'Dare Wilson, K. Community food environments and healthy food access among older adults: A review of the evidence for the Senior Farmers' Market Nutrition Program (SFMNP). Social Work Health Care 2017, 56, 227-243. [CrossRef]

68. Freedman, D.A.; Mattison-Faye, A.; Alia, K.; Guest, M.A.; Hébert, J.R. Peer reviewed: Comparing farmers' market revenue trends before and after the implementation of a monetary incentive for recipients of food assistance. Prev. Chronic Dis. 2014, 11. [CrossRef]

69. Dannefer, R.; Abrami, A.; Rapoport, R.; Sriphanlop, P.; Sacks, R.; Johns, M. A mixed-methods evaluation of a SNAP-Ed farmers' market-based nutrition education program. J. Nutr. Ed. Behav. 2015, 47, 516-525. [CrossRef]

70. Walkinshaw, L.P.; Quinn, E.L.; Rocha, A.; Johnson, D.B. An Evaluation of Washington State SNAP-Ed Farmers' Market Initiatives and SNAP Participant Behaviors. J. Nutr. Ed. Behav. 2018, 50, 536-546. [CrossRef]

71. Ritter, G.; Walkinshaw, L.P.; Quinn, E.L.; Ickes, S.; Johnson, D.B. An assessment of perceived barriers to farmers' market access. J. Nutr. Ed. Behav. 2019, 51, 48-56. [CrossRef]

72. Cohen, A.J.; Lachance, L.L.; Richardson, C.R.; Mahmoudi, E.; Buxbaum, J.D.; Noonan, G.K.; Murphy, E.C.; Roberson, D.N.; Hesterman, O.B.; Heisler, M.; et al. "Doubling Up" on produce at Detroit farmers markets: Patterns and correlates of use of a healthy food incentive. Am. J. Prev. Med. 2018, 54, 181-189. [CrossRef]

73. Durward, C.M.; Savoie-Roskos, M.; Atoloye, A.; Isabella, P.; Jewkes, M.D.; Ralls, B.; Riggs, K.; LeBlanc, H. Double Up Food Bucks participation is associated with increased fruit and vegetable consumption and food security among low-income adults. J. Nutr. Educ. Behav. 2019, 51, 342-347. [CrossRef]

74. Garner, J.A.; Coombs, C.; Savoie-Roskos, M.R.; Durward, C.; Seguin-Fowler, R.A. A qualitative evaluation of double up food bucks farmers' market incentive program access. J. Nutr. Educ. Behav. 2020, 52, 705-712. [CrossRef]

75. Zimmerman, G.; Roskos, M.S.; Feller, C.; Durward, C. Double up food bucks farmers' market incentive program: Food insecurity and fruit and vegetable consumption. FASEB J. 2016, 30, lb427.

76. Headrick, G.; Hecht, A.A.; Misiaszek, C.; Brosius, S.; Crone, A.; Surkan, P.J. Customers' Views on the Implementation of a Farmers Market Incentive Program: Successes and Opportunities for Improvement. J. Hunger Environ. Nutr. 2020, 1-17. [CrossRef]

77. Thilmany, D.; Bond, C.A.; Bond, J.K. Going local: Exploring consumer behavior and motivations for direct food purchases. Am. J. Agric. Econ. 2008, 90, 1303-1309. [CrossRef]

78. Andreatta, S.; Wickliffe, W., II. Managing farmer and consumer expectations: A study of a North Carolina Farmers Market. Hum. Org. 2002, 61, 167-176. [CrossRef]

79. Institute of Portland, Metropolitan Studies. Planting Prosperity and Harvesting Health: Trade-offs and Sustainability in the OregonWashington Regional Food System; Dillon, T., Nohad, A., Eds.; Toulan School of Urban Studies and Planning, College of Urban and Public Affairs: Portland, OR, USA, 2008.

80. Rasmussen, M.; Krølner, R.; Klepp, K.I.; Lytle, L.; Brug, J.; Bere, E.; Due, P. Determinants of fruit and vegetable consumption among children and adolescents: A review of the literature. Part I: Quantitative studies. Int. J. Behav. Nutr. Phys. Act. $2006,3,22$. [CrossRef] [PubMed]

81. Bomba, M. Promoting Farmers Markets in Los Angeles: Research Findings from the Market Together Project. Available online: https://www.oxy.edu/sites/default/files/assets/UEPI/Market\%20Together\%20Research\%20Report\%20FINAL.pdf (accessed on 2 March 2021).

82. Oberholtzer, L.; Grow, S. Producer-Only Farmers' Markets in the Mid-Atlantic Region; Henry, A., Ed.; Wallace Center for Agricultural and Environmental Policy: Arlington, VA, USA, 2003.

83. Market Umbrella. Farmers Markets Deliver What Communities NEED: Neighborhood Exchange Evaluation Device Measures Farmers Markets' Impact on Social Capital. Available online: https://www.frbsf.org/community-development/files/3bmccarthy-handout-2.pdf (accessed on 2 March 2021).

84. Lev, L.; Brewer, L.; Stephenson, G. Research Brief: How Do Farmers' Markets Affect Neighboring Businesses. Available online: https:/ / smallfarms.oregonstate.edu/sites/agscid7 / files/techreport16.pdf (accessed on 10 December 2019).

85. Econsult Corporation. Estimating the Economic Impact of Public Markets; Project for Public Spaces: New York, NY, USA, 2007.

86. Cummings, H.; Kora, G.; Murray, D. Farmers' Markets in Ontario and Their Economic Impact; University of Guelph School of Rural Planning \& Development: Ontario, CA, USA, 1999.

87. Henneberry, S.R.; Agustintini, H.N.; Taylor, M.; Mutondo, J.E.; Whitacre, B.; Roberts, B.W. The Economic Impacts of Direct Produce Marketing: A Case Study of Oklahoma's Farmers' Markets. In Proceedings of the Southern Agricultural Economics Association Annual Meeting, Dallas, TX, USA, 2-6 February 2008.

88. Harris, W. Direct Marketing. In Closer to Home: Healthier Food, Farms and Families in Oklahoma; McDermott, M., Ed.; Kerr Center for Sustainable Agriculture: Poteau, OK, USA, 2006; pp. 65-74. 
89. MarketUmbrella. Sticky Economy Evaluation Device: Measuring the Financial Impact of a Public Market. Available online: https://www.crescentcityfarmersmarket.org/uploads/downloads/SEED_Economic_Impact_Report_2017.pdf (accessed on 4 March 2021).

90. Myles, A.; Hood, K.W. Economic Impact of Farmers' Markets in Mississippi; Mississippi State University: Starkville, MS, USA, 2010.

91. Hughes, D.W.; Brown, C.; Miller, S.; McConnell, T. Evaluating the Economic Impact of Farmers' Markets Using an Opportunity Cost Framework. J. Agric. Appl. Econ. 2008, 40, 253. [CrossRef]

92. Hughes, D.W.; Isengildina-Massa, O. The economic impact of farmers' markets and a state level locally grown campaign. Food Policy 2015, 54, 78-84. [CrossRef]

93. Shuman, M.H. Going Local: Creating Self-Reliant Communities in a Global Age; Routledge Press: New York, NY, USA, 1998.

94. Kane, S.P.; Wolfe, K.; Jones, M.; McKissick, J. The Local Food Impact: What if Georgians Ate Georgia Produce? University of Georgia Center for Agribusiness and Economic Development: Athens, GA, USA, 2010.

95. Shapira, I. Purist Farmers Markets Shun Coffee Roasters. Available online: https://www.washingtonpost.com/local/puristfarmers-markets-shun-coffee-roasters/2012/04/16/gIQAurYVMT_story.html (accessed on 3 March 2021).

96. Swenson, D. Investigating the Potential Impacts of Local Foods for Southwest Iowa; Pirog, R., Adams, M.A., Eds.; Leopold Center for Sustainable Agriculture at Iowa State University: Ames, IA, USA, 2010.

97. Meter, K. Local Food as Economic Development; Crossroads Resource Center: Minneapolis, MN, USA, 2008.

98. Jablonski, B.B.; McFadden, D.T. IN THIS ISSUE: What Is a 'Multiplier' Anyway? Assessing the Economics of Local Food Systems Toolkit. J. Agric. Food Syst. Community Dev. 2019, 8, 1-8. [CrossRef]

99. Thilmany McFadden, D.; Bauman, A.; Jablonksi, B.B. The financial performance implications of differential marketing strategies: Exploring farms that pursue local markets as a core competitive advantage. In Proceedings of the 2016 AAEA Annual Meetings, Boston, MA, USA, 31 July-2 August 2016.

100. Sadler, R.C.; Clark, M.A.; Gilliland, J.A. An economic impact comparative analysis of farmers' markets in Michigan and Ontario. J. Agric. Food Syst. Community Dev. 2013, 3, 61. [CrossRef]

101. Hilchey, D.; Thomas, L.; Gilbert, G. Farmers' Markets and Rural Economic Development: Entrepreneurship, Business Incubation, and Job Creation in the Northeast. In Farming Alternatives Program; Department of Rural Sociology, Cornell University: Ithaca, NY, USA, 1995.

102. Varner, T.; Otto, D. Factors affecting sales at farmers' markets: An Iowa study. App. Econ. Perspect. Pol. 2008, 30, 176-189. [CrossRef]

103. Alkon, A.H.; McCullen, C.G. Whiteness and farmers markets: Performances, perpetuations ... contestations? Antipode 2011, 43, 937-959. [CrossRef]

104. Kahkonen, S.; Krishna, A.; Pantoja, E.; Reid, C.; Salmen, L.F.; Shrader, E. Understanding and Measuring Social Capital-A Multidisciplinary Tool for Practitioners; Grootaert, C., Van Bastelar, T., Eds.; World Bank Group: Washington, DC, USA, 2002.

105. Holeva, P.D. Growing Social Capital: Investigating the Relationship between Farmers' Markets and the Development of Community Support Networks in Ann Arbor, MI; Miami University: Miami, FL, USA, 2009.

106. Lyson, T.A.; Gillespie, G.W., Jr.; Hilchey, D. Farmers' markets and the local community: Bridging the formal and informal economy. Am. J. Altern. Agric. 1995, 10, 108-113. [CrossRef]

107. Lyson, T.A. Civic Agriculture: Reconnecting Farm, Food, and Community; Tufts University Press: Boston, MA, USA, 2004.

108. Hawe, P.; Shiell, A. Social capital and health promotion: A review. Soc. Sci. Med. 2000, 51, 871-885. [CrossRef]

109. Lin, N. Building a network theory of social capital. In Social Capital: Theory and Research; Lin, N., Cook, K.S., Burt, R.S., Eds.; Routledge Press: Abington-on-Thames, UK, 2001.

110. Lochner, K.; Kawachi, I.; Kennedy, B.P. Social capital: A guide to its measurement. Health Place 1999, 5, 259-270. [CrossRef]

111. Martin, K.S.; Rogers, B.L.; Cook, J.T.; Joseph, H.M. Social capital is associated with decreased risk of hunger. Soc. Sci. Med. 2004, 58, 2645-2654. [CrossRef] [PubMed]

112. Freedman, D.A.; Vaudrin, N.; Schneider, C.; Trapl, E.; Ohri-Vachaspati, P.; Taggart, M.; Cascio, M.A.; Walsh, C.; Flocke, S. Systematic review of factors influencing farmers' market use overall and among low-income populations. J. Acad. Nutr. Diet. 2016, 116, 1136-1155. [CrossRef] [PubMed]

113. Rice, J.S. Privilege and exclusion at the farmers market: Findings from a survey of shoppers. Agric. Hum. Values 2015, 32, 21-29. [CrossRef]

114. Mayes, L.M. Nutrition Knowledge and Dietary Habits of Farmers Market Patrons. Master's Thesis, University of Kentucky, Lexington, KY, USA, 2013.

115. Racine, E.F.; Mumford, E.A.; Laditka, S.B.; Lowe, A.E. Understanding characteristics of families who buy local produce. J. Nutr. Educ. Behav. 2013, 45, 30-38. [CrossRef]

116. Wolf, M.; Spittler, A.; Ahern, J. A profile of farmers' market consumers and the perceived advantages of produce sold at farmers' markets. J. Food Distrib. Res. 2005, 36, 192-201.

117. Alkon, A.H. From value to values: Sustainable consumption at farmers markets. Agric. Hum. Values 2008, 25, 487-498. [CrossRef]

118. Alkon, A.H. Black, White, and Green: Farmers Markets, Race, and the Green Economy; University of Georgia Press: Athens, GA, USA, 2012; Volume 13.

119. Pilgeram, R. Social sustainability and the white, nuclear family: Constructions of gender, race, and class at a Northwest farmers' market. Race Gender Class 2012, 19, 37-60. 
120. McClintock, N. Cultivating (a) sustainability capital: Urban agriculture, ecogentrification, and the uneven valorization of social reproduction. Ann. Am. Assoc. Geogr. 2018, 108, 579-590. [CrossRef]

121. Alkon, A.H.; Cadji, J. Sowing seeds of displacement: Gentrification and food justice in Oakland, CA. Int. J. Urban Reg. Res. 2020, 44, 108-123. [CrossRef]

122. United States Department of Agriculture Economic Research Services. Food Dollar Service. 2013. Available online: https: / / data.nal.usda.gov/dataset/food-dollar-series (accessed on 4 March 2021).

123. Detre, J.D. Linkage between direct marketing and farm income: A double-hurdle approach. Agribusiness 2010, 27, 19. [CrossRef]

124. Hardesty, S.D.; Leff, P. Determining marketing costs and returns in alternative marketing channels. Renew. Agric. Food Syst. 2009, 25, 24-34. [CrossRef]

125. Martinez, S.; Hand, M.; Da Pra, M.; Pollack, S.; Ralston, K.; Smoth, R.; Vogel, T.; Clark, S.; Lohr, L.; Low, S.; et al. Local Food Systems: Concepts, Impacts, and Issues. In Economic Research Report; United States Department of Agriculture, Economic Research Service: Washington, DC, USA, 2010.

126. Tropp, D.; Barham, J. National Farmers Market Summit Proceedings Report; Marketing Services Division, USDA Agricultural Marketing Service: Washington, DC, USA, 2008.

127. Integrity Systems Cooperative Co.; Sustainability Ventures Group. Adding Value to Our Food System: An Economic Analysis of Sustainable Community Food Systems; United States Agriculture Sustainable Agriculture Research and Education Program \& University of Utah: Salt Lake City, UT, USA, 1997.

128. Hinrichs, C.; Gillespie, G.; Feenstra, G. Social Learning and Innovation at Retail Farmers Markets. Rural Soc. 2004, 69, 31-58. [CrossRef]

129. Kimmons, J.; Jones, S.; McPeak, H.H.; Bowden, B. Developing and Implementing Health and Sustainability Guidelines for Institutional Food Service. Advanc. Nutr. Int. Rev. J. 2012, 3, 337-342. [CrossRef]

130. Cameron, A. Farmers' markets as small business incubators and safety nets: Evidence from New Zealand. Int. J. Entrep. Behav. Res. 2007, 13, 367-379. [CrossRef]

131. Govindasamy, R.; Hossain, F.; Adelaja, A. Income of farmers who use direct marketing. Agric. Resour. Econ. Rev. 1999, $28,76-83$. [CrossRef]

132. Archambault, S.; Trivette, S.; Warsaw, P.; Morales, A. Vendor Variety and Market Sales. J. Agric. Food Syst. Community Dev. 2020, 9 , 1-17. [CrossRef]

133. Ragland, E.; Tropp, D. Farmers Market Manager Survey; U.S. Department of Agriculture: Washington, DC, USA, 2009.

134. National Public Radio. Why Are So Many Farmers Markets Failing? Because The Market Is Saturated. Available online: https:/ / www.npr.org/sections / thesalt/2019/03/17/700715793/why-are-so-many-farmers-markets-failing-because-themarket-is-saturated (accessed on 2 March 2021).

135. Pirog, R.S.; Benjamin, A. Checking the Food Odometer: Comparing Food Miles for Local Versus Conventional Produce Sales to Iowa institutions. 2003. Available online: https://lib.dr.iastate.edu/cgi/viewcontent.cgi?article=1149\&context=leopold_ pubspapers (accessed on 2 March 2021).

136. Weber, C.L.; Matthews, H.S. Food-miles and the relative climate impacts of food choices in the United States. Environ. Sci. Technol. 2008, 42, 10, 3508-3513. [CrossRef] [PubMed]

137. Coley, D.; Howard, M.; Winter, M. Food miles: Time for a re-think? Br. Food J. 2008, 113, 919-934. [CrossRef]

138. Van Passel, S. Food miles to assess sustainability: A revision. Sustain. Dev. 2013, 21, 1-17. [CrossRef]

139. Schnell, S.M. Food miles, local eating, and community supported agriculture: Putting local food in its place. Agric. Hum. Values 2013, 30, 615-628. [CrossRef]

140. Farmers Market Coalition. Farmers Markets Promote Sustainability. Available online: http://farmersmarketcoalition.org/ education/farmers-markets-promote-sustainability / (accessed on 1 March 2021).

141. Gale, F. Direct farm marketing as a rural development tool. Rural Dev. Perspect. 1997, 12, $19-25$.

142. U.S. Department of Agriculture. 2011 Certified Organic Production Survey; U.S. Department of Agriculture, National Agricultural Statistics Service: Washington, DC, USA, 2012.

143. Payne, T. US Farmers' Markets 2000: A Study of Emerging Trends; US Dept. of Agriculture, Marketing and Regulatory Programs, Agricultural Marketing Service, Transportation and Marketing Programs, Marketing Services Branch: Washington, DC, USA, 2002.

144. United States Department of Agriculture. Farmers Market Manager Highlights. Available online: https://downloads.usda. library.cornell.edu/usda-esmis/files/pz50hd694/gx41n598k/jd473j98z/nfar0820.pdf (accessed on 28 February 2021).

145. Herman, D.R.; Harrison, G.G.; Jenks, E. Choices Made by Low-Income Women Provided with an Economic Supplement for Fresh Fruit and Vegetable Purchase. J. Am. Diet. Assoc. 2006, 106, 740-744. [CrossRef] [PubMed]

146. Leischow, S.J.; Milstein, B. Systems thinking and modeling for public health practice. Am. J. Public Health 2006, 96, 403-405. [CrossRef]

147. Malhi, L.; Karanfil, O.; Merth, T.; Acheson, M.; Palmer, A.; Finegood, D.T. Places to Intervene to Make Complex Food Systems More Healthy, Green, Fair, and Affordable. J. Hunger Environ. Nutr. 2009, 4, 466-476. [CrossRef] [PubMed] 
148. Thilmany McFadden, D.; Conner, D.; Deller, S.; Hughes, D.; Meter, K.; Morales, A.; Schmit, T.; Swenson, D.; Bauman, A.; Phillips Goldenberg, M.; et al. The Economics of Local Food Systems: A Toolkit to Guide Community Discussions, Assessments, and Choices. U.S. Department of Agriculture, Agricultural Marketing Service, March 2016. Available online: https://www.ams. usda.gov/publications / content/economics-local-food-systems-toolkit-guide-community-discussions-assessments (accessed on 3 March 2021).

149. Farm2Facts. Available online: https:/ / farm2facts.org/ (accessed on 4 March 2021).

150. Heldke, L. Alfonso Morales, Jane Addams, and Liberty Hyde Bailey: Models of Democratic Research. Pluralist 2019, 14, 55-62. [CrossRef]

151. Suerth, L.C. Citizen Participation Actionable Knowledge in Food Systems Practice; Dissertation; The University of Wisconsin-Madison: Madison, WI, USA, 2019. 